\title{
Short review of some methods for groundwater flow assessment in fractured rock masses
}

\section{Breve revisione su alcuni metodi per l'analisi della circolazione idrica negli ammassi rocciosi fratturati.}

Paola Gattinoni, Laura Scesi

\begin{abstract}
Riassunto: La circolazione idrica negli ammassi rocciosi fratturati costituisce un elemento chiave nella risoluzione di molti problemi tipici dell'ingegneria civile and ambientale. Tuttavia, gli acquiferi in rocce fratturate sono storicamente meno studiati di quelli nei mezzi porosi, in parte perché sono considerati meno rilevanti dal punto di vista della ricerca idrica, in parte perché gli ammassi rocciosi sono un mezzo estremamente complesso (eterogeneo, anisotropo e discontinuo), e quindi la loro modellazione è più dispendiosa e comunque più difficile. Questo articolo propone una revisione delle ricerche nazionali e internazionali sul tema della circolazione idrica negli ammassi rocciosi fratturati. In particolare, vengono affrontati i principali aspetti connessi alla ricostruzione del modello concettuale, con riferimento principalmente alle rocce fessurate e in parte a quelle carsiche, per poi discutere criticamente la scelta dell'approccio di modellazione più adatto, anche attraverso esempi applicativi.
\end{abstract}

\begin{abstract}
Water flow in fractured rock masses is a key issue in many typical environmental and engineering problems. Still, aquifers in fractured rocks are devoted much less attention than those in porous media, as they are considered less important from the point of view of water research, but also because rock masses are a very complex medium (beterogeneous, anisotropic and discontinuous), and therefore its modelling is a quite hard task. This paper proposes a review on recent researches concerning groundwater flow in fractured rock masses. In particular, the main issues involved in the reconstruction of the bydrogeological conceptual model are addressed, mainly for fissured and partly for karsts rocks, and the following choice of the most suitable modeling approach is critically discussed, through applicative examples.
\end{abstract}

Keywords: fractured rocks, groundwater flow, hydrogeological conceptual model, hydraulic properties, numerical modelling.

Parole chiave: rocce fratturate, flusso delle acque sotterranee, modello concettuale idrogeologico, proprietà idrodinamiche, modellazione numerica.

\section{Paola GATTINONI 棒:}

Dept. of Civil and Environmental Engineering

Politecnico di Milano

\section{Laura SCESI}

Dept. of Civil and Environmental Engineering

Politecnico di Milano

Ricevuto/Received: 04 September 2018-Accettato/Accepted: 13 September 2018 Pubblicato online/Published online: 27 September 2018

This is an open access article under the CC BY-NC-ND license: http://creativecommons.org/licenses/by-nc-nd/4.0/

(C) Associazione Acque Sotterranee 2018

\section{Introduction}

Groundwater flow in fractured rock masses occurs through a system of "vacuums" connected to cooling phenomena, stratification, schistosity, fractures and faults of tectonic origins, karsts phenomena, etc. (Fig. 1). These discontinuity networks divide the rock mass in portions of intact rock and the water flow results strongly influenced by the geometric and mechanical characteristics of those discontinuities. Therefore, knowing their features and distribution is fundamental to model the groundwater flow in rock masses and then to solve the related applicative issues, such as tunnel inflow assessment, slope stability analysis, protection of mountain springs, etc.

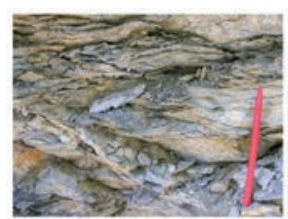

(a)

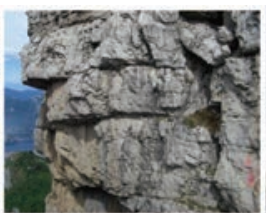

(b)

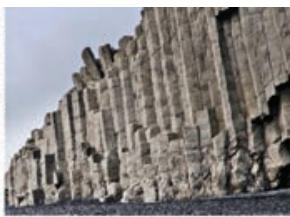

(c)
Fig. 1 - Typical examples of fractured rock masses characterized by different kind of discontinuities: (a) schistosity, (b) fractures; (c) cooling cracks

Fig. 1 - Esempi tipici di ammassi rocciosi, caratterizzati da diversi tipi di discontinuità: (a) scistosità, (b) fratture; (c) giunti di raffreddamento.

Many Authors already demonstrated that the permeability of fractures can be orders of magnitude higher than the matrix rock blocks (Scesi and Gattinoni 2009); as a consequence, the hydraulic behavior is neither homogeneous nor isotropic and the water flow is controlled by the fracture network and in particular by:

- $\quad$ joint dip and dip direction (Kiraly et al. 1971; Louis 1974),

- $\quad$ joint features (i.e. aperture, filling, roughness; Snow 1969; Scesi and Gattinoni 2007),

- $\quad$ fracturing degree (i.e. joint spacing, frequency and persistence; Lee and Farmer 1993; Min et al. 2004),

- discontinuities connectivity (Long and Witherspoon 1985; Rouleau and Gale 1985; Meyer and Einstein 2002),

- $\quad$ lithostatic load (mainly depending on depth), which can bring about great changes of the joints aperture (Bandis et al. 1983; Bai et al. 1999; Liu et al. 2000).

This paper intends to review and synthesize some researches on the topic of groundwater flow in rock masses starting from the evaluation of the hydraulic conductivity, passing through the definition of the conceptual model and the following choice of the numerical modeling approach. The focus of the paper is mainly on fissured rock masses, but the applicability 
of the proposed methods to karsts rocks is also shortly addressed, with reference to the behavior of dominant karsts networks and the surrounding annex-to-drain system. After a discussion of the main theoretic aspects, some examples are proposed and discussed, showing the main differences among continuum, discrete and combined approaches.

\section{Hydraulic conductivity assessment}

Usually, the groundwater flow in fractured rock masses is ruled by the orientation and hydraulic features of joints. Therefore, for the conceptual model definition it is fundamental to carry out geostructural and hydrogeological surveys at different scales (Table 1): at regional scale it is important to verify the stress field that generated the fractures, as it can affect their hydraulic behavior, as well as to identify the regional groundwater flow system; at local scale, the geological-technical and hydrogeological studies are aimed at defining the main hydrogeological parameters (i.e., the groundwater level) and the hydraulic features of discontinuities.

Surface data should be integrated through in-depth information, arising from drillings and geophysical surveys (for the in-depth reconstruction of the fracture zones), as well as from in bore-hole permeability tests.

In a non-saturated rock mass, the water flow inside discontinuities is ruled by gravity, therefore water tends to flow in depth following the dip direction of discontinuities, especially the ones with high hydraulic conductivity. The water percolation goes on till it reaches either a water table (in that case, a flowing condition occurs in the saturated medium that is ruled by the hydraulic gradient of the aquifer) or an impermeable layer acting as a bedrock (Fig. 2). Afterwards, saturated condition occurs and the groundwater flow is ruled by the hydraulic gradient between recharge and discharge zone.

To determine the hydraulic behaviour of fractured rock masses it is important to take following elements into consideration:

- the permeability of the single discontinuity set, mainly depending on its aperture and roughness;

- the number and interconnection among the sets, depending on their spacing and persistence;

- the orientation of each set that rules the hydraulic conductivity tensor.

\section{Hydraulic conductivity along a single discontinuity set}

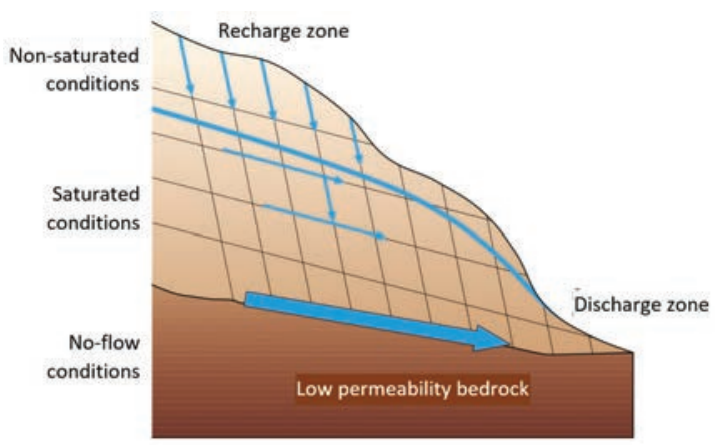

Fig. 2 - Example of percolation (in non-saturated condition) and flow (in saturated condition) in a fractured rock mass (drawing of Giuseppe Maserati, modified from Scesi et al. 2015).

Fig. 2 - Esempio di percolazione (nel non saturo) a filtrazione (nel saturo) in un ammasso roccioso (disegno di Giuseppe Maserati, modificato da Scesi et al. 2015).

The hydraulic conductivity value for a single smooth joint and in laminar flow condition can be expressed as:

$$
K=\frac{\gamma e^{2}}{12 \eta}=\frac{g e^{2}}{12 v}
$$

where $e(\mathrm{~m})$ is the joint mean aperture, $g\left(\mathrm{~ms}^{-2}\right)$ is the gravitational acceleration and $\eta\left(\mathrm{kg} / \mathrm{m}^{-1} \mathrm{~s}^{-1}\right), \quad \gamma\left(\mathrm{kgm}^{-3}\right)$, $v\left(\mathrm{~m}^{2} \mathrm{~s}^{-1}\right)$ are respectively the dynamic viscosity, the specific weight and the kinematic viscosity of the fluid.

If the flow regime (laminar, turbulent, and inertial) and

Tab. 1 - Surveys and analysis for the hydrogeological characterization of fractured rock masses at different scales.

Tab. 1 - Indagini e analisi per la caratterizzazione idrogeologica degli ammassi rocciosi a diverse scale di lavoro.

\begin{tabular}{|l|l|l|}
\hline \multirow{2}{*}{ Characterizing factors } & \multicolumn{1}{|c|}{ Surveys and analysis } \\
\cline { 2 - 3 } Joints & $\begin{array}{l}|c| \\
\text { Analysis of the regional tectonics for } \\
\text { stress field reconstruction. } \\
\text { Photointerpretation for master joints } \\
\text { orientation. } \\
\text { Laserscanning for frequency and } \\
\text { persistence }\end{array}$ & $\begin{array}{l}\text { In situ geologicial-structural survey } \\
\text { (orientation, spacing, aperture, } \\
\text { persistence, roughness, etc.). } \\
\text { Geophysical surveys for in-depth } \\
\text { analysis of fracture zones. }\end{array}$ \\
\hline Hydraulic conductivity & $\begin{array}{l}\text { Hydrogeochemical survey (e.g., tracer } \\
\text { tests or depletion function of springs) }\end{array}$ & $\begin{array}{l}\text { Structural data elaboration (for surface } \\
\text { evaluation). } \\
\text { In bore-hole permeability tests (for in } \\
\text { depth evaluation) }\end{array}$ \\
\hline Water table and gradient & Discharge points (i.e., springs) & \begin{tabular}{l} 
Piezometers \\
\hline
\end{tabular}
\end{tabular}


the joints' roughness in terms of relative asperities height are taken into consideration, the equations to determine the hydraulic conductivity are listed in Table 2 . In this way, it is possible to apply this approach for the hydraulic conductivity assessment not only to fissured systems, but also to karst ones, where a shape roughness is usually present and the regime is quite often turbulent.

Joint roughness reduces the effective aperture of discontinuities and its influence increases as the aperture gets smaller. Various studies were carried out mesauring how roughness and fracture apertures variations affect water flow; they highlighted that rouhness and undulation of the discontinuities walls determine points of contacts and rock bridges that can be modelled through various statistical distributions of joints apertures. In the presence of rough joints, the application of a load can also considerably affect the permeability values of the joint; actually, dilatancy phenomena determine variations of the hydraulic aperture of the joints that are strictly correlated to those of the mechanic aperture.

In the applied geology field, in order to determine the hydraulic conductivity of a rock mass, the joint roughness becomes crucial only if the height of asperities is rilevant when compared to the joint aperture. That means working generally in relative roughness $\varepsilon / D b>0.033$, corresponding to inertial flow.

To consider spacing and frequency, Snow (1970) proposed following relation that is true for smooth joints and laminar condition:

$$
K=\frac{e^{3} f g}{12 v}
$$

where $f$ is the frequency $\left(\mathrm{m}^{-1}\right)$. Obviously, also in this case it is possible to obtain different formulas for all flow regimes, like in Table 2.

\section{Interconnection among sets of discontinuity}

A further aspect to consider for describing the hydraylic behaviour of fractured rock masses is the degree of interconnection among the different discontinuities; actually, if fractures are independent from each other, they behave as isolated bonds that do not contribute to the shift of the fluid mass. On the contrary, if the discontinuities are interconnected, hydraulic conductivity is influenced by all discontinuity families present in the rock mass and the water flow follows a real flow network formed by a series of bonds connected to each other.

Rouleau and Gale (1985) proved that interconnection $\left(\mathrm{I}_{\mathrm{ij}}\right)$ between two discontinuity families may be expressed as a function of other parameters characteristic of the same discontinuity families, such as orientation, spacing and persistence:

$$
I_{i j}=\frac{l_{i}}{S_{i}} \sin \gamma_{i J}
$$

Tab. 2 -Relations for the bydraulic conductivity in different flow regimes. $R e=$ Reynolds Number, $\varepsilon=$ asperity heigth, $D h=2 e$ (reprinted by permission from Springer Hydrogeology Journal - modified from Gattinoni and Scesi 2007).

Tab. 2 - Relazioni per la valutazione della permeablità nei diversi regimi di moto. $R e=$ numero di Reynolds, $\varepsilon=$ altezza delle asperità, $D h=2 e$ (ristampato col permesso di Springer Hydrogeology Journal - da Gattinoni e Scesi 2007,

\begin{tabular}{|c|c|c|c|}
\hline & Condition & Flow law & $\begin{array}{l}\text { Unitary flow } \\
\left(\mathrm{m}^{2} / \mathrm{s}\right)\end{array}$ \\
\hline \multirow{3}{*}{$\begin{array}{l}\varepsilon / \mathrm{D}_{\mathrm{h}}<0,033 \\
\text { (surface } \\
\text { roughness) }\end{array}$} & Laminar & $\lambda=\frac{96}{\mathrm{Re}}$ & $q_{i}=\frac{g e_{i}^{3}}{12 v} J_{i}$ \\
\hline & $\begin{array}{l}\text { Turbolent } \\
\text { (smooth } \\
\text { walls) }\end{array}$ & $\lambda=0.316 \mathrm{Re}^{-1 / 4}$ & $q_{i}=\left[\frac{g}{0.079}\left(\frac{2}{v}\right)^{1 / 4} e_{i}^{3} \cdot J_{i}\right]^{4 / 7}$ \\
\hline & $\begin{array}{c}\text { Turbolent } \\
\text { (rough walls) }\end{array}$ & $\frac{1}{\sqrt{\lambda}}=-2 \log \frac{\frac{\varepsilon}{D_{h}}}{3.7}$ & $q_{i}=4 \sqrt{g}\left(\log \frac{3.7}{\frac{\varepsilon}{D_{h}}}\right) e_{i}^{1.5} \sqrt{J_{i}}$ \\
\hline \multirow{2}{*}{$\begin{array}{l}\varepsilon / D_{\mathrm{h}}>0,033 \\
\text { (shape } \\
\text { roughness) }\end{array}$} & Inertial & $\lambda=\frac{96}{\operatorname{Re}}\left[1+8.8\left(\frac{\varepsilon}{D_{h}}\right)^{1.5}\right]$ & $q_{i}=\frac{g e_{i}^{3}}{12 v\left(1+8.8\left(\frac{\varepsilon}{D_{h}}\right)^{1.5}\right)} J_{i}$ \\
\hline & Turbolent & $\frac{1}{\sqrt{\lambda}}=-2 \log \frac{\frac{\varepsilon}{D_{h}}}{1.9}$ & $q_{i}=4 \sqrt{g}\left[\log \left(\frac{1.9}{\varepsilon / D_{h}}\right)\right] e_{i}^{1.5} \sqrt{J_{i}}$ \\
\hline
\end{tabular}
modificata).

where $l_{i}$ e $s_{i}$ are respectively the length $(\mathrm{m})$ and the average spacing $(\mathrm{m})$ of the $i^{t h}$ discontinuity family, whereas $\gamma_{\mathrm{ij}}$ is the angle between the two discontinuity families. In general, it happens that:

$$
I_{i j}=I_{j i}
$$

If $m$ represents the number of discontinuity families inside the rock mass, the comprehensive interconnection of the $i^{t h}$ discontinuity family is given by:

$$
I_{i}=\sum_{j=1}^{m} I_{i j} \quad \mathrm{i} \neq \mathrm{j}
$$

Naturally, when $I_{i}$ increases, the load of the ith discontinuity family increases from the hydraulic point of view. The unit is assumed as the limit value of the interconnection index $\mathrm{I}_{\mathrm{i}}$ :

- $\quad$ if $\mathrm{I}_{\mathrm{i}}>1$, the ith discontinuity family is interconnected with the rest of the discontinuous system;

- $\quad$ if $\mathrm{I}_{\mathrm{i}}<1$, the ith discontinuity family is isolated from the rest of the discontinuous system.

Some Authors (Shante and Kirkpatrick 1971; Gueguen and Dienes 1989) developed the percolation theory to calculate the hydraulic conductivity depending on persistence and interconnection. According to that theory, single 
discontinuities in rock masses are assimilated to bonds with finite length, whose hydraulic conductivity is a function of the aperture, whereas their intersections create the "percolation site".

The hydraulic conductivity therefore depends on the percolation frequency $v(-)$, as follows

$$
k=\frac{4 \pi v e^{3} r^{2}}{15 s^{3}} \cdot \frac{g \rho}{v}
$$

where $e$ is the effective aperture $(\mathrm{m}), r=2 \mathrm{~L} / \pi$, with $\mathrm{L}(\mathrm{m})$ equal to the average discontinuity length (Phal 1981), $s$ is the average discontinuity spacing $(\mathrm{m}) ; \rho$ and $v$ are respectively the fluid density $\left(\mathrm{kgm}^{-3}\right)$ and dynamic viscosity $\eta\left(\mathrm{kg} / \mathrm{m}^{-1} \mathrm{~s}^{-1}\right)$, and $g$ the gravity acceleration $\left(\mathrm{ms}^{-2}\right)$.

\section{The hydraulic conductivity tensor of fractured rock masses}

The anisotropy of hydraulic conductivity of fractured rock masses is mainly affected by orientation and number of fracture sets (Rong et al. 2013).

To take into account the orientation of the discontinuities, the hydraulic conductivity is expressed as a tensor (Kiraly et al. 1971):

$$
\overline{\bar{K}}=\sum_{i=1}^{m}\left[\left(e_{i}^{3} \cdot g \cdot f_{i}\right) \div 12 v\right] \overline{\overline{A_{i}}}
$$

where $\overline{\bar{K}}$ is the conductivity tensor $(\mathrm{m} / \mathrm{s}), g$ the standard gravity acceleration $\left(\mathrm{m} / \mathrm{s}^{2}\right), v$ the water kinematic viscosity $\left(\mathrm{m}^{2} \mathrm{~s}^{-1}\right), e_{i}$ and $f_{i}$ respectively the average discontinuities aperture $(\mathrm{m})$ and frequency $(1 / \mathrm{m})$ of the $\mathrm{i}^{\text {th }}$ family; $m$ is the number of discontinuity families, $\overline{\bar{A}}_{i}=(\overline{\bar{I}}-\bar{n} \otimes \bar{n})$ the orientation tensor, with $\overline{\bar{I}}$ equal to the fundamental tensor (identity matrix) and $\bar{n}$ equal to the normal vector to the mean plane of the discontinuity set.

The tensor thus obtained can be used as representative of the hydraulic conductivity of the rock mass considered as a continuum even if anisotropic medium (Fig. 3). The geometric mean of the three main components of the tensor can be used as representative of the equivalent hydraulic conductivity $(\mathrm{Ke})$ of the rock mass considered as an isotropous medium (Louis 1974):

$$
K e=\left(K_{1} K_{2} K_{3}\right)^{1 / 3}
$$

In order to verify this hypothesis, it is necessary to define the Representative Elementary Volume (REV), that is the minimal volume to take into consideration to study the hydrogeological features of a rock mass, such that the medium can be considered sufficiently homogeneous and isotropic (Bear 1972). In a rock mass, the REV must contain all the discontinuity families and therefore it can change, according to the fracturing degree, from $1 \mathrm{~m}^{3}$ to $10^{6} \mathrm{~m}^{3}$ (Fig. 4) Recent researches have shown that the REV size is mainly influenced by trace length, spacing and number of fracture sets (Rong et al. 2013).
As a consequence, for domain dimension smaller than the $\mathrm{REV}$, the water flow in fractured rock masses is ruled by the hydraulic conductivity of the single fractures, whereas for domain dimension wider than the REV, the rock mass can be assimilated to an anisotropic continuum and the tensor of the hydraulic conductivity can be considered representative for the groundwater flow reconstruction.
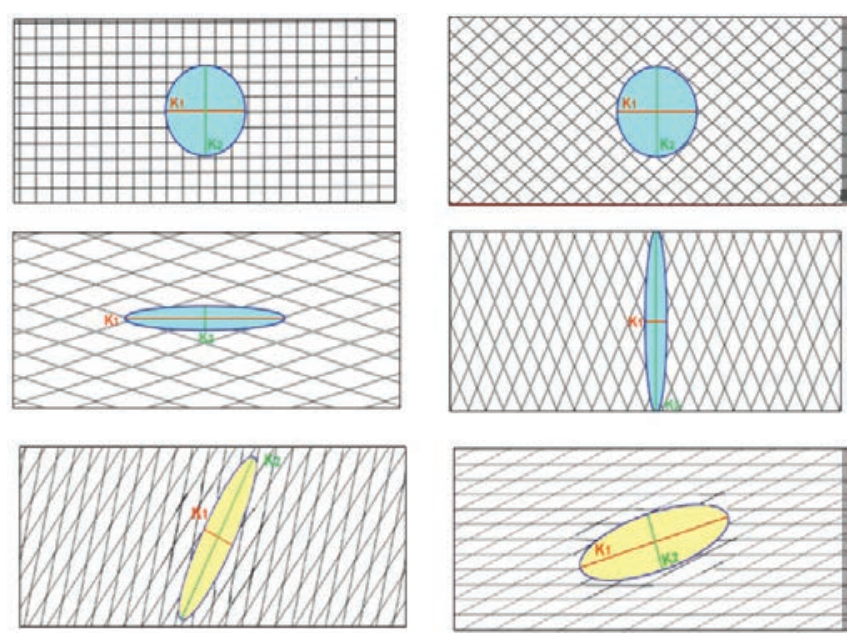

Fig. 3 - Examples of joint networks, with the corresponding permeability ellipses in a vertical plane. $K_{1}$ and $K_{2}$ are the main bydraulic conductivity components (reprinted by permission from Springer Hydrogeology Journal Gattinoni E Scesi, 2010).

Fig. 3 - Esempi di reticoli fessurativi con le corrispondenti ellissi di permeabilità nel piano verticale. $\mathrm{K}_{1}$ e $\mathrm{K}_{2}$ sono le due componenti principali della permeabilità. Ristampato col permesso di Springer Hydrogeology Journal, da Gattinoni \& Scesi (2010).
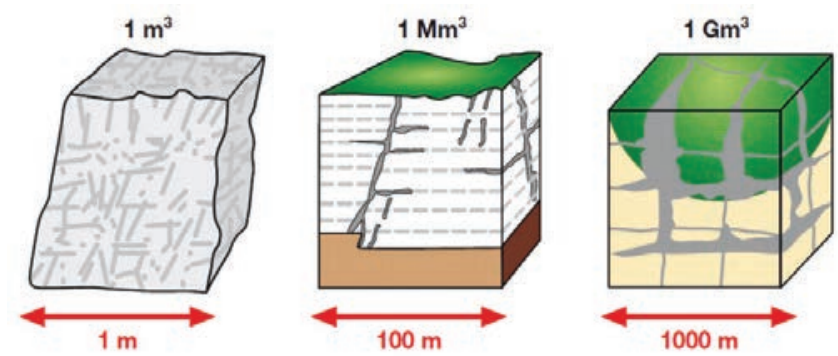

Fig. 4 - Examples of rock masses having different REV: (a) fissured rock, (b) fractured rock, (c) karstic rock (modified from Civita 2005).

Fig. 4 - Esempi di ammassi rocciosi caratterizzati da diversi REV: (a) roccia intensamente fessurata, (b) roccia fratturata, (c) roccia carsico (da Civita 2005, modificato).

\section{Hydraulic conductivity from in situ tests}

At small scale, the most common in-situ tests for estimating the hydraulic conductivity of rock masses are pumping tests (Maréchal et al. 2008; Van Tonder et al. 2002) and Lugeon tests (Lugeon 1933). These areborehole tests allowing to obtain an isotropic equivalent value of the hydraulic conducitvity. Kazemi (1969) proposed a method to estimate the main hydrogeological parameters of dual permeability aquifers, whereas for anisotropic aquifers the most commonly used methods have been developed by Papadopulos (1969), 
Hantush (1966) and Neuman et al. (1984).

Recently, some researchers have tested inferred thermography for the study of rock masses, proving that their cooling behaviour is related to their degree of fracturing and then to their hydraulic conductivity (Pappalardo 2018).

At large scale, hydraulic conductivity can be determined using hydrogeochemical methods, based on the water residence time (Edmunds and Smedley 2000; Tweed et al. 2005) or on the use of artificial tracers (Vigna 2001), which also helps in the definition of the hydrogeological conceptual model.

\section{The hydrogeological conceptual model}

The starting point for reconstructing the hydrogeological conceptual model is the geological model, as it rules the type of aquifer and the presence of aquicludes or aquitards (see for instance La Vigna et al. 2013), the permeability distribution, and then the groundwater flow path (Fig. 5). As far as this latter is concerned, the trend of the groundwater table must be defined as well as the hydrogeological balance at the scale of interest. At this aim, the boundaries of the groundwater basin should be identified, as:

- impermeable boundaries (aquicludes): very low permeability rocks, which prevent the water exchange;

- discharge or recharge boundaries: surface water bodies which supply (or are supplied by) the groundwater;

- flow boundaries: groundwater divides.

Once, the hydrogeological basin has been characterised in term of geological setting and main flow path direction, the hydrodynamic features of the aquifer must be quantified. At this aim, the development of a hydrogeological conceptual model in a rock mass requires the knowledge of the geometry and orientation of the rock joints at the scale of interest (Table 1). Based on the features of the joints previously described

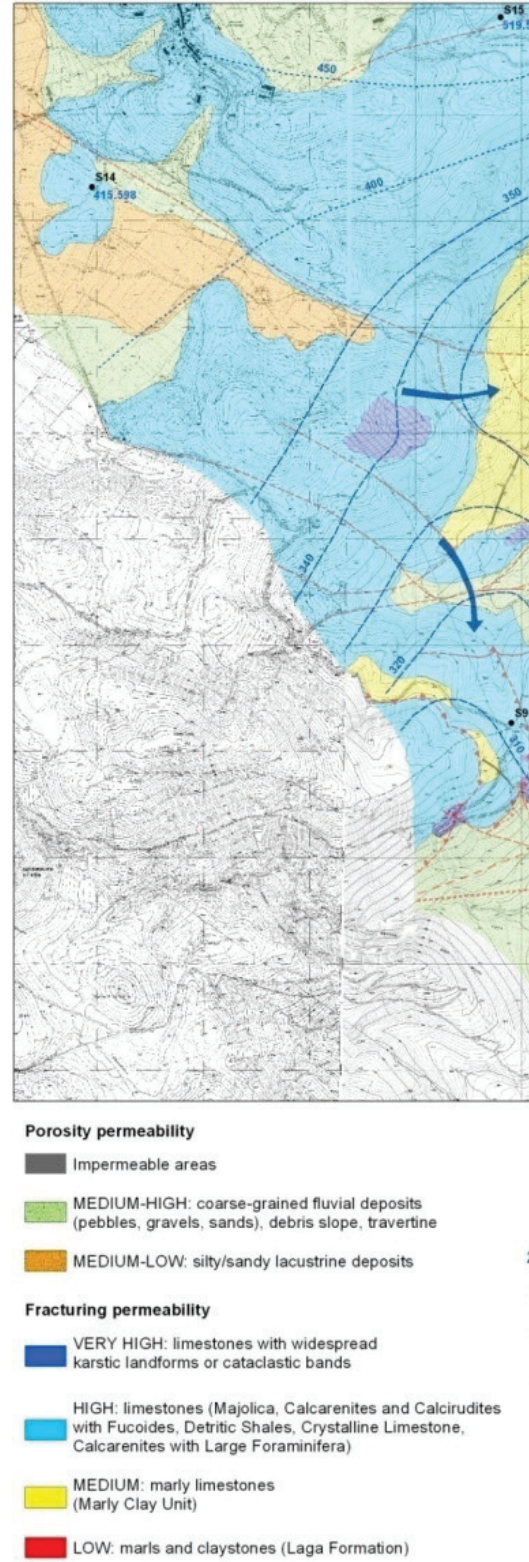

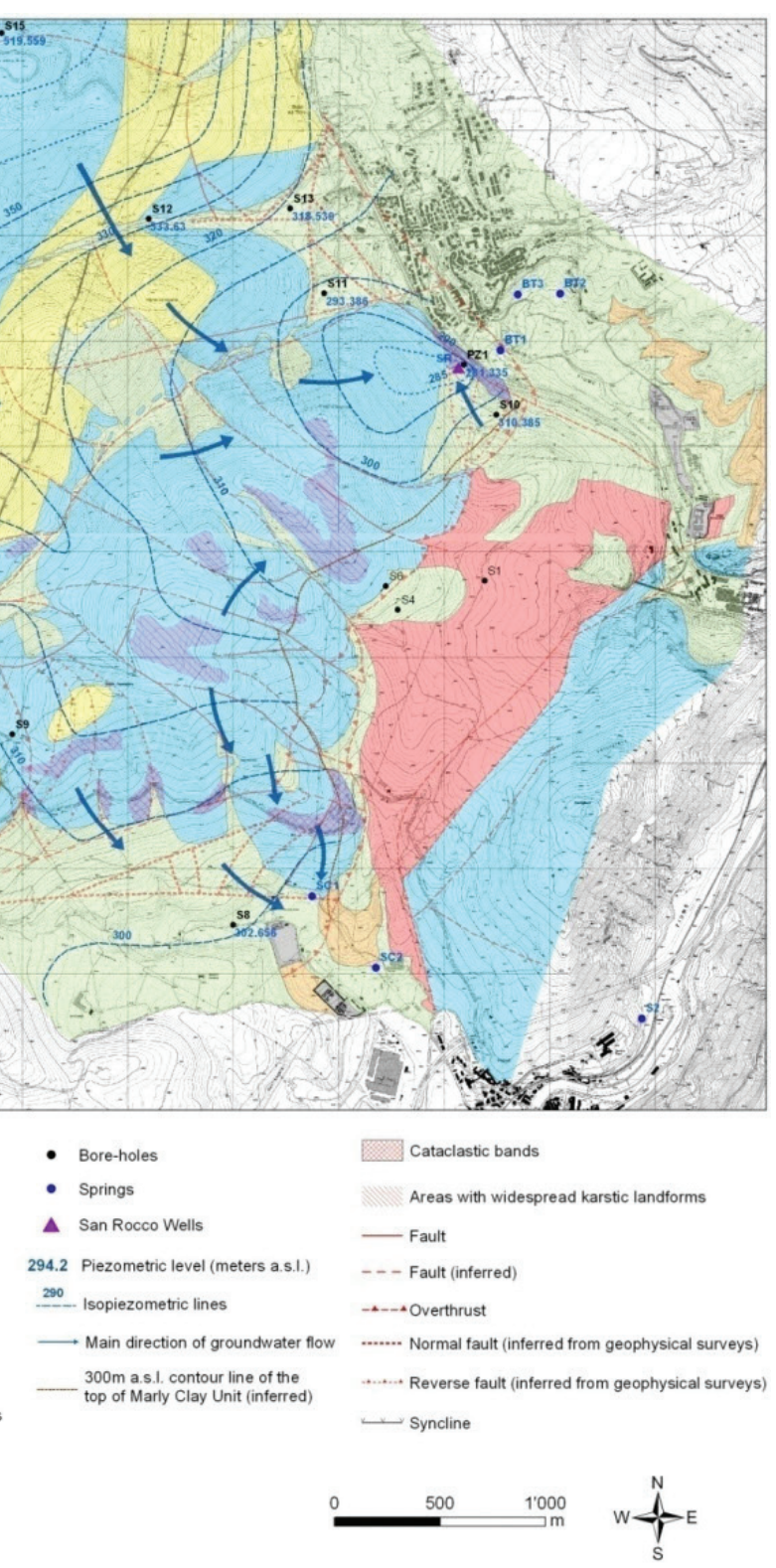

Fig. 5 - Example of hydrogeological map, in which the type of permeability (and then the type of aquifer) and the main groundwater flow direction is defined (Biava et al. 2014).

Fig. 5 - Esempio di carta idrogeologica, nella quale vengono definiti i tipi di permeabilità (e di conseguenza la tipologia di acquifero), nonché le direzioni di flusso principali (Biava et al. 2014) 
(mainly on degree of fracturing and persistence), three mean kinds of flow network can be identified (Fig. 6):

- Dominant drain: the rock mass is characterized by a low fracturing degree and a main joint set rules the groundwater flow (such as many kasrst systems), whereas the other minor joint sets have low persistence and do not contribute to the flow; in this case, there exist in the rock mass main flow paths;

- Multiple drains: there exist two or three well developed joint sets, having a good persistence and connectivity; therefore, the groundwater flow takes place in a wide and articulated network of fractures;

- Dispersive structure: in the rock mass doesn't exist any main flow path, as the rock mass is characterized by a high degree of fracturing with several persistent and well interconnected joint sets.

In the first case, the flow is certainly ruled by the joints features, whereas in the third one the rock mass can be studied as a continuum. The second case can be assimilated to both a discrete network and a continuum. In this case, the definition of the hydrogeological conceptual model has to consider the following aspects:

- $\quad$ the work scale (Bear and Berkowitz 1987);

- the fracturing degree (e.g. the REV);

- the changing of fracturing degree in the space, in particular with depth.

As regard the work scale, in a near and very near field the water flow generally occurs inside a single fracture or in a small number of well defined fractures, whose shapes and position are known, and that may also be reconstructed with a statistical approach (Dershowitz and Einstein 1988; Min et al. 2004 and references therein). For problems on lower scales (far and very far field) equivalent porous media approaches can generally be applied. Obviously the choice depends not only on the work scale, but also on the fracturing degree of the rock mass (La Poine et al. 1996) that defines the REV. Also the anisotropy of the rock mass permeability is scale dependent: the larger the observation scale, the more isotropic become the permeability (Yang et al. 2017).

In addition to the work scale and the fracturing degree, in the conceptual model definition it has to be taken into account that experimental observations show a reduction of the frequency of fracturing as depth increases, linked with a reduction of the aperture of joints (Snow 1969). This determines an often quite relevant decrease of the effective fracture porosity with depth, with a correlated decrease of the permeability. In reality, the definition of the trends in depth of the above mentioned geometric features of discontinuities is often quite difficult and experimental tests carried out by different Authors during the years have often provided contrasting results. According to some Authors, for examples, beyond a superficial unit of weathered rock, where the fracturing frequency is higher, permeability remains almost constant in depth (Raven and Gale 1976); permeability changes should therefore be linked to aperture changes more than to variations in the intensity of fracturing, even though the presence of wide open joints in depth is not uncommon, with extremely variable permeability values that could not be easily reproduced by means of empirical laws, in particular when depth exceeds $500 \mathrm{~m}$ (Brace 1980).

On the basis of the previously described information for modelling purpose, the rock mass domains can be classified as (Fig. 7):

- Poorly fractured rock: the corresponding conceptual model is a continuum model, in which an equivalent hydraulic conductivity or the corresponding tensor has to
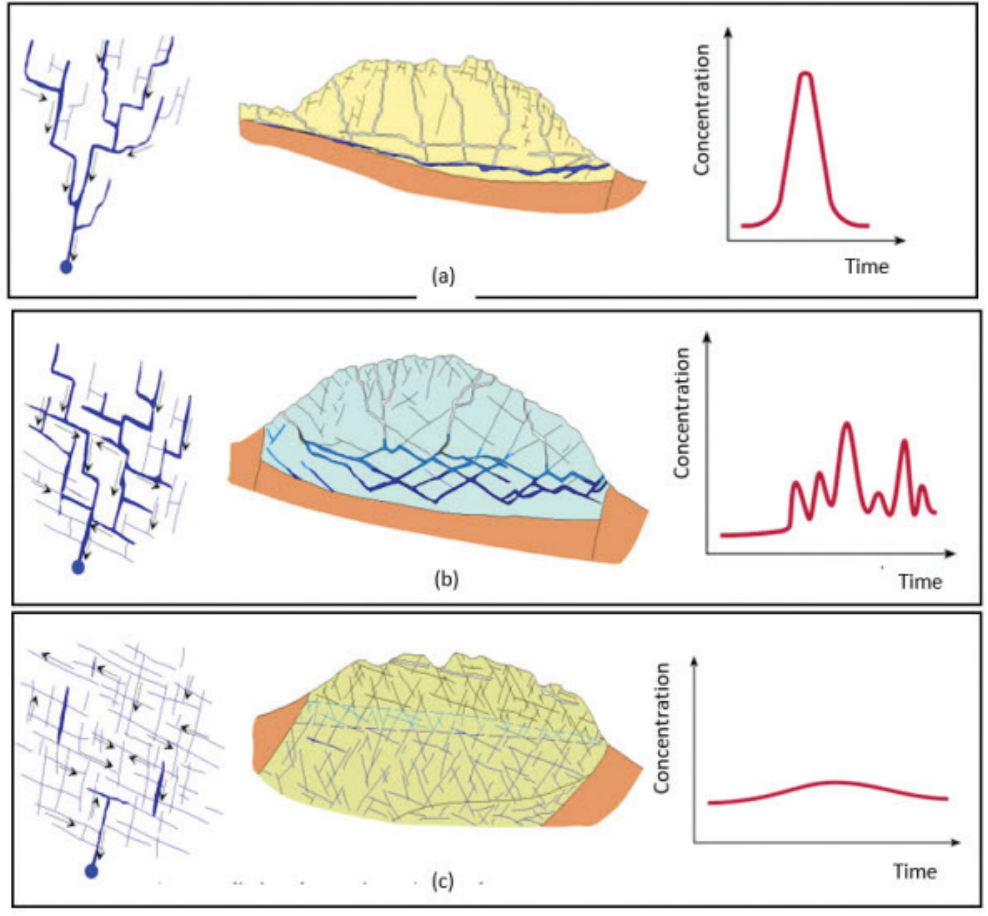

Fig. 6 - Flow network typology in rock masses: (a) dominant drain, (b) multiple drains, (c) dispersive, with the corresponding tracer response functions (modified from Vigna 2001).

Fig. 6 - Tipologie di reticoli fessurativi con le relative funzioni di risposta dei traccianti: (a) a dreno dominante, (b) a dreni multipli, (c) dispersiva (da Vigna 2011, modificata). 
be defined for the different homogenous zones;

- High-density fracture network: it can be idealized as both a single continuum or a double continuum, according to data availability;

- Dominant single fractures: the corresponding conceptual model is a discrete fracture model, in which joints features and distribution have to be well known;

- Dominant single fractures in addition to rock matrix: it can be idealized as both a double continuum model or a combination of continuum and discrete fracture model; in the latter case, characterization of both continuum and joints features are needed, in addition to an exchange function

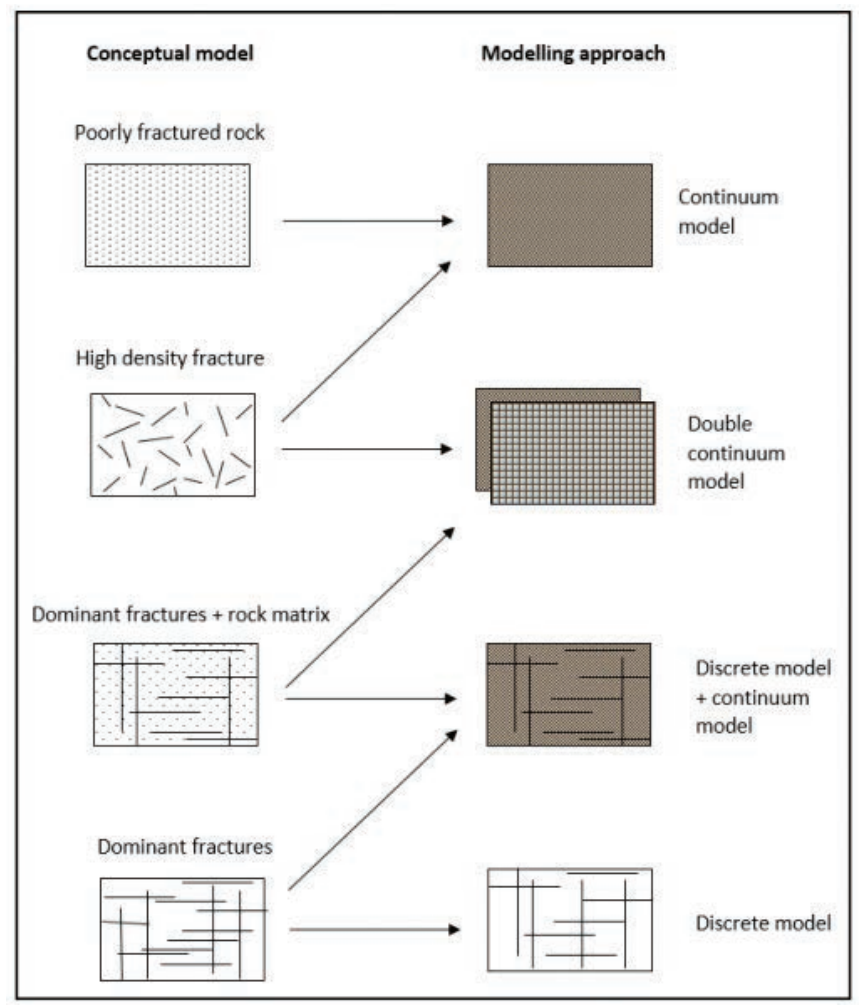

Fig. 7 - Classification of the conceptual models and the corresponding modeling approaches.

Fig. 7 - Classificazione del modello concettuale e corrispondenti possibili approcci modellistici.

\section{From conceptual to numerical modeling}

As far as groundwater flow simulation is concerned, in the last decades numerical models have become very useful tools, in which the fundamental flow equations are solved on the basis of known boundary and initial conditions. Obviously, the first step of the modelling procedure, after the conceptual model definition, is the choice of the general equation describing the phenomena, i.e., the choice of the modelling approach.

Different numerical strategies have been proposed to model groundwater flow in fractured rock masses, among which the continuum based models have been widely used.
In that case the fractured rock mass is simplified either as a single continuum (representing homogenized features of both fractures and matrix blocks), or dual continuum (consisting of two overlapping media with different hydraulic properties).

When dealing with an equivalent continuum (porous media) approach, there are two key parameters that should be determined: the REV size and the equivalent permeability tensor. The existence and size of the REV directly determine the applicability of the equivalent continuum approach, and the permeability tensor characterise the flow parameters.

However, REV do not always exist in naturally fractured rocks. Thus, discrete models have to be developed to simulate each individual fracture. They can fall into two categories depending on weather they neglect the permeability of the rock matrix (Discrete Fracture Models) or they account the matrix flow together with the fracture flow (Hybrid Models).

The choice of the most suitable model in a specific case study depends on the previously defined conceptual models. The choice whether to use the one or the other method is made also on the basis of the available geological-structural data and the work scale, always considering that the results provided by numerical modeling may contain errors linked both to the limited ability of the model itself to represent the real geological structure and to the difficulty of characterizing the discontinuity network at the required scale.

\section{Continuum models}

The continuous approach is based on the REV, which assumes the existence of a threshold size, over which the mean hydraulic properties of the rock mass reach a stable value. As a consequence, continuum models with equivalent properties are efficient for large-scale numerical simulations.

When the medium is considered a continuum, it is possible to use the models able to solve the fundamental equation of flow in porous media.

One of the most used numerical code is Modflow (Harbaugh et al. 2000), which solves the flow equation in 3-D through a finite difference method at central cells. At this aim the domain is divided with a mesh, having cell of dimension larger than the REV. As the presence of extended shear zones highly conditions the groundwater flow, the continuum models have to keep into account the presence of these structural features that represent basic elements in the ruling of groundwater flow. To solve the problem, boundary conditions have to be defined: constant head, constant flux or head depending on flux. Generally, the results obtained from the application of Darcy's models underline how strongly the model calibration is influenced by the dimension of the cells used and the availability of field measures.

Previous Authors demonstrated that the distributed parameter approach of the equivalent porous media can be successfully used to simulate large scale groundwater flow in a fractured-karstified aquifer (Fig. 8), especially when:

- the fracture/conduit systems supplying the spring are fairly uniform and well interconnected (Croci et al. 2003; La Vigna et al., 2016); 
- the objective of the model is to simulate spring discharge (Scanlon et al. 2003; Francani and Gattinoni 2010);

- only data on spring discharge are available for model calibration (Angelini and Dragoni 1997).

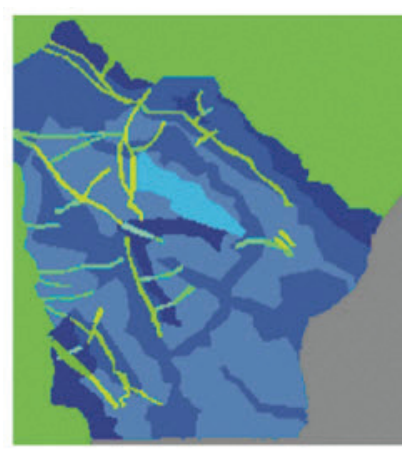

(a)

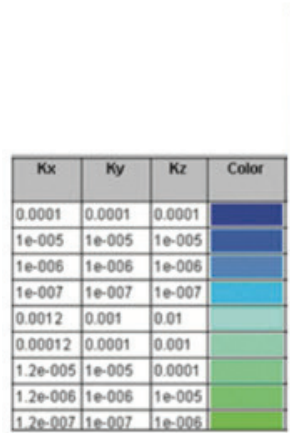

(c)

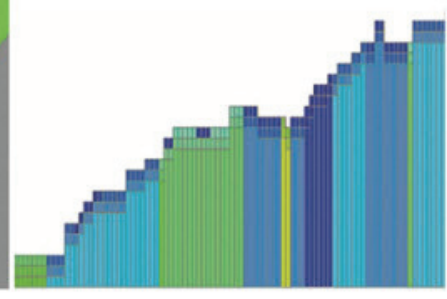

(b)

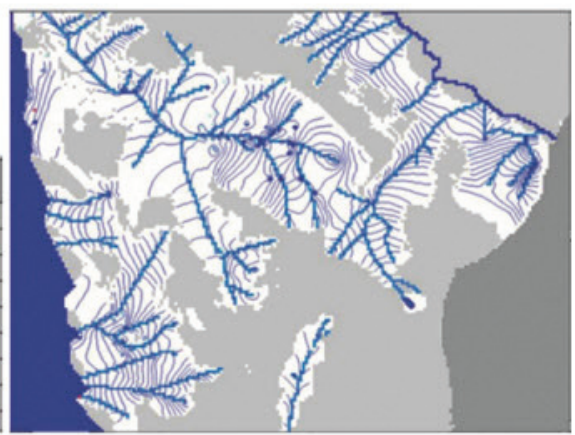

(d)
Fig. 8 - Example of continuum numerical model of a fractured rock mass: (a) planar view of the domain, (b) cross section view, (c) bydraulic conductivity values (in $\mathrm{m} / \mathrm{s}),(d)$ modelling results (modified from Croci et al. 2003).

Fig. 8 - Esempio di modello numerico continuo applicato ad un ammasso roccioso fratturato. (a) planimetria del dominio, (b) vista in sezione, (c) valori di permeabilità (in m/s), (d) risultati della modellazione (da Croci et al. 2003 modificato).

\section{Discrete models}

The continuum approach is no longer valid if the system is studied on a detailed scale, as this scale requires discrete flow models. This implies the need to generate a discontinuity network and to apply the appropriate boundary conditions to it, in order to decide which are the most suitable numerical techniques for the flow forecast. Discrete models developed both in two dimensions (Robinson 1982) and in a threedimensional field (Dverstorp and Andersson 1989) explicitly simulate the flow of each single discontinuity using, for example, the Navier-Stokes equation (Bear 1993), Kirchoff's laws for electric circuits (Kraemer and Haitjema 1989) or the model with hydraulically connected circular disks (Cacas et al. 1990).

The huge amount of fractures in a model often make numerical simulations impractical, therefore some Authors (Ren et al. 2017) recently proposed an equivalent densityreduced discrete fracture network modelling method.

In that field, the application of numerical models with distinct elements arises particular interest; they can analyze the groundwater flow both in a two-dimensional and a threedimensional field, coupled with the geomechanical analysis. The calculation scheme starts from the water pressure within the single joint, which can bring about a change in the joint aperture, depending on its mechanical properties. The joint permeability is calculated through the Snow equation, as depending on the hydraulic joint aperture, which in turn depends on the surface aperture plus a joint normal displacement due to the mechanical effects. Afterwards, based on the joint permeability and the water pressure, a flow rate is calculated along the joints and then into the nodes, in order to obtain water pressure changes and then the cycle goes on until convergence is reached.

Obviously, such an approach requires the availability of high quantities of data and, as a consequence, it was used more often for the study of tunnel inflows (Molinero et al. 2002).

For example, Gattinoni and Scesi (2010) proposed an example of tunnel inflow assessment in a small diameter tunnel, located at a medium depth within sedimentary rocks. The tunnel was divided into hydrogeological and geo-structural homogeneous stretches and for each one the hydraulic conductivity tensor and the corresponding equivalent hydraulic conductivity were calculated based on the geostructural survey (Fig. 9). The hydraulic conductivity ellipses in the vertical planes orthogonal to the tunnel direction, show a considerable anisotropy. For each homogeneous stretch a discrete model was used to assess tunnel inflow.

The simulation was compared with results of different approaches:

- traditional analytic equations, in which the tunnel inflow assessment is based on the equivalent hydraulic conductivity of the rock mass;
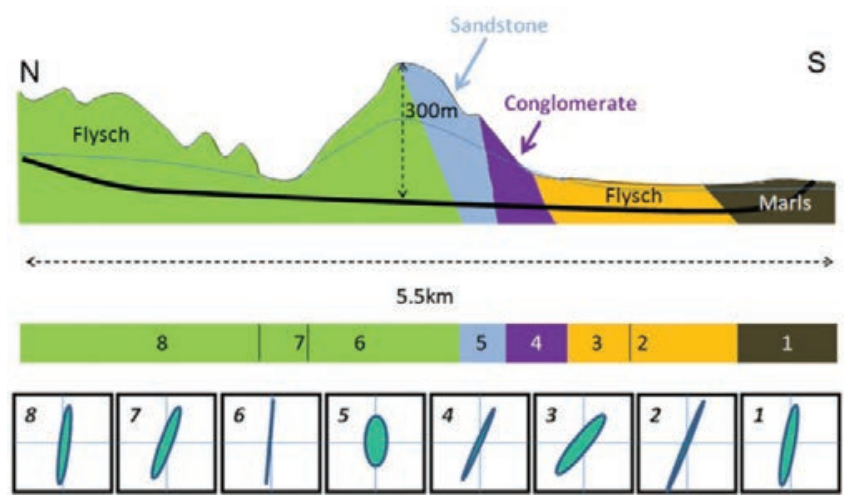

Fig. 9 - Geological cross section along the tunnel (shown as the dark line). The blue line is the water table. The numbers 1-8 indicate the homogeneous stretches in which the tunnel was divided, for which the hydraulic conductivity ellipses (in the plane orthogonal to the tunnel axes) are shown (reprinted by permission from Springer Hydrogeology Journal Gattinoni E Scesi 2010).

Fig. 9 - Sezione di previsione di una galleria (in nero, mentre in blu è indicato il livello piezometrico). I numeri da 1 a 8 indicano i tratti omogenei per i quali sono state ricavate le ellissi di permeabilità (nel piano verticale ortogonale all'asse della galleria). Ristampato col permesso di Springer Hydrogeology Journal, da Gattinoni \& Scesi (2010). 
- 3D continuum groundwater flow modelling, in which the tensor of hydraulic conductivity is considered, assimilating the rock mass to an anisotropic and heterogeneous continuum.

The results obtained with the different approaches were then compared with the tunnel monitoring data, arising from the flow rate measured in the tunnel channel at different tunnel distances. The results comparison (Fig. 10) showed that the continuum hypothesis (which is at the base of Goodman's analytic equation) brings about highly overestimated values of the tunnel water inflow, especially in that sections where the rock mass anisotropy is higher, with maximum hydraulic conductivity in the direction close to the vertical.

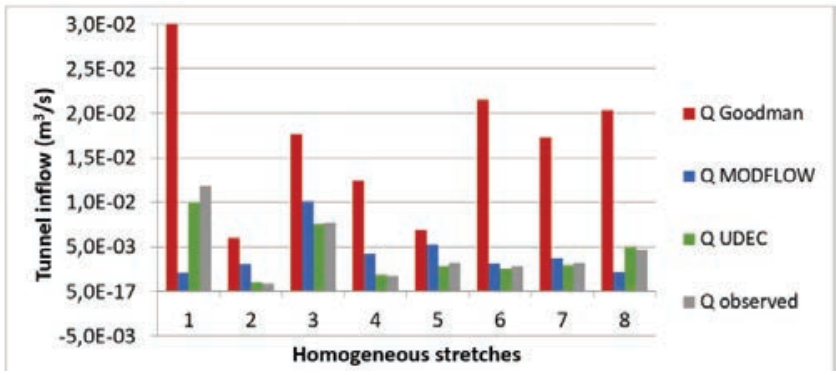

Fig. 10 - Comparison between the observed tunnel inflow with tunnel inflow obtained through different approaches presented in Figure 10: Goodman's analytic equation (Goodman et al. 1965), Modflow equivalent continuum numerical model, UDEC distinct element numerical model.

Fig. 10 - Confronto tra le venute d'acqua osservate in galleria e quelle stimate con diversi approcci presentati in Figura 10: la formula analitica di Goodman et al. (1965), il modello continuo equivalente implementato in Modflow e il modello numerico agli elementi distinti implementato col software UDEC.

\section{Combined approach: dual porosity and dual permeability models}

Dual porosity models (introduced by Barenblatt et al. in 1960) try to combine the simplification of Darcy's models with the complexity of discrete models, taking into account, at the same time but still separating from one another, the water flow within intact rock (primary porosity) and that of the discontinuity network (secondary porosity). Actually, in dual porosity models, equations are used that can rule both continuous and fractured media, among which flow exchange at the interface is possible (Fig. 11). Generally, dual porosity models are used to simulate the flow and transportation of contaminants (Bai et al. 1997; Moutsopoulos et al. 2001; Alboin et al. 2002) as these elements may have relevant interaction with the rock matrix, mainly in relation to the propagation and dispersion of the contaminant. Some limitations of dual porosity models are represented by the little realistic adoption of a very simplified geometry of rock masses and by the fact that the advection in the rock matrix is generally neglected.

The delay in the hydraulic response of rock masses, well described by the dual porosity models as a consequence of the high storage coefficient of the rock matrix, is often influenced also by the presence of small but very frequent

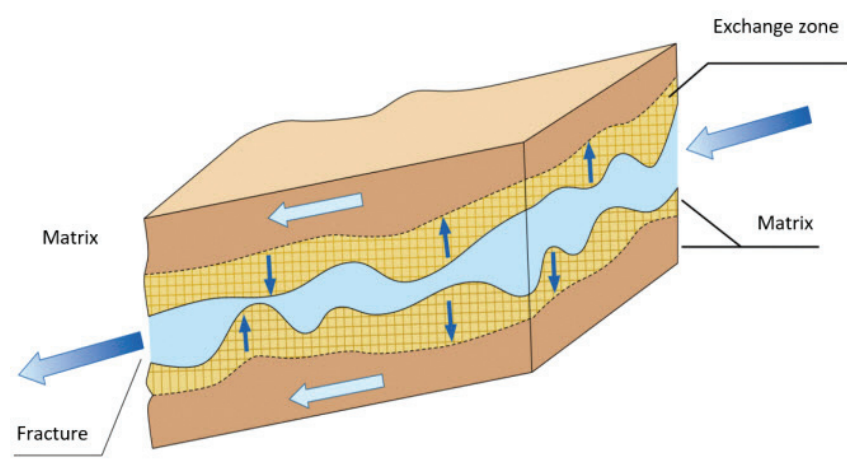

Fig. 11 - Flow exchange between rock matrix and fracture in combined approach (drawing of Giuseppe Maserati, from Scesi et al. 2015).

Fig. 11 - Scambio idrico tra matrice e frattura in un approccio combinato (disegno di Giuseppe Maserati, da Scesi et al. 2015).

fractures in the rock matrix, especially in the nearby area of the master joints (Fig. 12). Therefore, rock matrix achieves a not negligible permeability with the possibility of local flow and water exchanges with the master joints. In this case "double permeability models" can be more useful to better describe the phenomena.

For instance, the Conduit Flow Process package implemented in Modflow 2005 allows to perform dual permeability simulations, with a combined approach, overlapping a continuum medium with a discrete network.

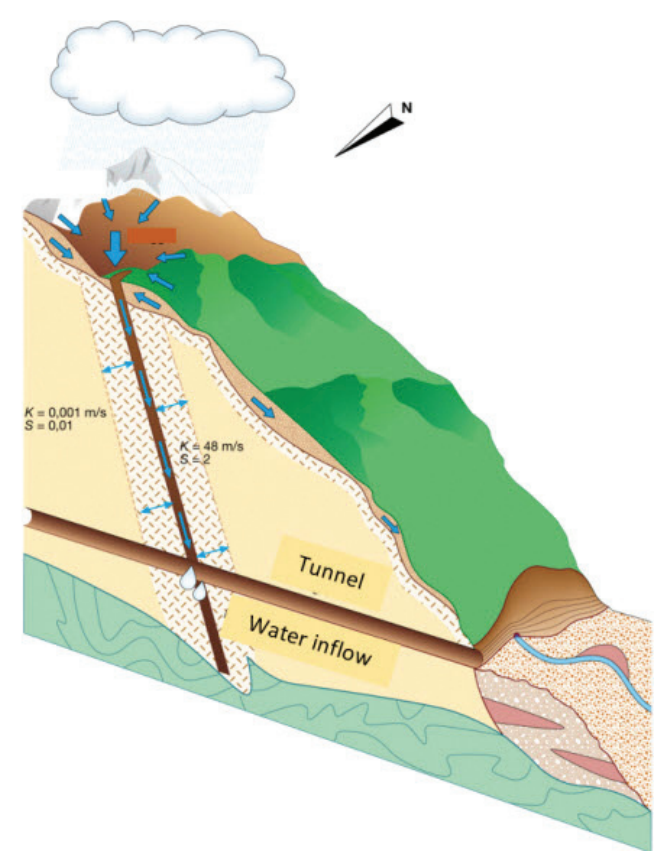

Fig. 12 - Example of conceptual model of a dual permeability system (drawing of $G i$ useppe Maserati, modified from Scesi et al. 2015), characterised by a wide master joint (aperture over $0.15 \mathrm{~m}$ ) surrounded by a network of small interconnected fractures. For the master joint the equation for turbulent regime (Table 2) has been used.

Fig. 12 - Esempio di modello concettuale di un sistema a doppia permeabilità (disegno di Giuseppe Maserati, modificato da Scesi et al. 2015), caratterizzato da una frattura molto aperta (apertura maggiore di $0,15 \mathrm{~m}$ ) circondata da un reticolo fessurativo molto pervasivo ma con minori aperture. Per il condotto principale si son utilizzate le equazioni relative al regime di moto turbolento (Tabella 2). 
Figure 13 shows an example of results for the conceptual model in Figure 12, showing that a dual permeability model allows to reproduce the secondary peaks in spring discharge observed by the monitoring system.

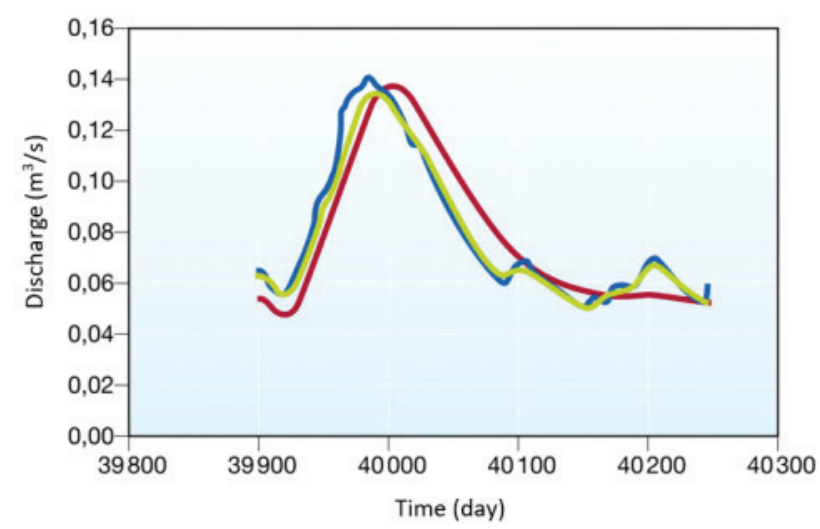

Observed - Equivalent continuum

Dual permeability

Fig. 13 - Spring discharge (see the conceptual model in Fig. 10) simulated with different modelling approach (drawing of Giuseppe Maserati, modified from Scesi et al. 2015).

Fig. 13 - Portata della sorgente (si veda il corrispondente modello concettuale in Fig. 10) simulata con diversi approcci modellistici (disegno di Giuseppe Maserati, modificato da Scesi et al. 2015).

\section{Conclusions and future perspective}

Groundwater flow assessment in rock masses is a key issue in the resolution of many engineering, geotechnical and hydrogeological problems in both mountain and plain regions, such as:

- to identify the recharge and discharge areas of an aquifer and to relate them with the stability conditions of the slopes;

- to reconstruct the flow path induced by tunnelling and forecast the water inflow location, discharge rate as well as the water table drawdown;

- to characterize the rocky aquifers for supply and protection of groundwater resources, as well as for geothermal purposes;

- to reconstruct the water circulation in the rocks near dams to define the preferential flow directions and avoid losses.

As water flow in fractured rock masses mainly occurs along discontinuities, the exact knowledge of their origin, distribution, and features is fundamental in assessing the hydraulic conductivity and describing the fluid flow.

This paper reviewed the research on water flow in rock masses and outlined the key aspects of both hydraulic conductivity definition and modelling approach. As far as the latter is concerned, many examples are available in the international literature, but few of them are really able to reproduce the flow complexity at local scale (intermediate between the large scale of spring catchment basin and the very small scale of laboratory tests), especially with reference to the discrete fracture models.

\section{REFERENCES}

Alboin C, Jaffre J, Joly P, Roberts J, Serres C (2002) A comparison of methods for calculating the matrix block source term in a double porosity model for contaminant transport. Comput Geosci 6: 523543.

Angelini P, Dragoni W (1997) The problem of modelling limestone springs: the case of Bagnara (North Apennines, Italy). Ground Water 35(4): 612-618.

Bai M, Elsworth D, Roegiers JC (1997) Triple-porosity analysis of solute transport. J Contam Hydro 28: 247-266.

Bai M, Meng F, Elsworth D, Roegiers JC (1999) Analysis of stressdependent permeability in non orthogonal flow and deformation fields. Rock Mech Rock Eng 32(3): 195-219.

Bandis SC, Barton NR, Christianson M (1985) Application of a new numerical model of joint behaviour to rock mechanics problems. In Proceedings of the International Symposium on Fundamentals of Rock Joints, Bjorkliden, September 1985, Luleå, Sweden: Centek, pp. 345-356.

Barenblatt GE, Zheltov IP, Kochina IN (1960) Basic concepts in the theory of seepage of homogeneous fluids in fissured rocks. J Appl Math and Mech 24: 1286-1303.

Bear J (1972) Dynamics of Fluids in Porous Media, Elsevier, New York.

Bear J (1993) Modelling flow and contaminant transport in fractured rocks. In Bear J, Tsang CF, DeMarsily G (eds) Flow and Contaminant Transport in Fractured Rock, Academic Press, San Diego (California), pp. 1-10.

Bear J, Berkowitz B (1987) Groundwater flow and pollution in fractured rock aquifers. In Nowak P (ed) Development in Hydraulic Engineering, vol. 4, Elsevier, New York.

Biava F, Consonni M, Francani V, Gattinoni P, Scesi L (2014) Delineation of Protection Zones for the Main Discharge Area of the Gran Sasso Aquifer (Central Italy) through an Integrated Geomorphological and Chronological Approach, Journal of Water Resources and Protection, 6: 1816-1832. http://dx.doi.org/10.4236/ jwarp.2014.619161.

Brace WF (1980) Permeability of argillaceous and crystalline rocks. Int J Rock Mech Min Sci \& Geomech Abstr 17: 241-251.

Cacas MC, Ledoux E, DeMarsily G, Tillie B, Barbreau A, Durand E, Feuga B, Peaudecerf P (1990) Modelling fracture flow with a stochastic discrete fracture network: calibration and validation 1 . The flow model. Water Resources Res 26: 479-789.

Civita M (2005) Idrogeologia applicata e ambientale "Applied and environmental hydrogeology". Casa Editrice Ambrosiana, Milano.

Croci A, Francani V, Gattinoni P (2003) Studio idrogeologico del bacino del Torrente Esino "Hydrogeological study of the Esino River". Quaderni di geologia applicata, 10(2): 148-166.

Dershowitz WS, Einstein HH (1988) Characterizing rock joint geometry with joint system models. Rock Mech Rock Eng 21(1): 21-51.

Dverstorp B, Andersson J (1989) Application of the discrete fracture network concept with field data: possibilities of model calibration and validation. Water Resources Res 25(3): 540-550.

Edmunds WM, Smedley PL (2000) Residence time indicators in groundwater: the East Midlands Triassic sandstone aquifer. Applied Geochem 15: 737-752.

Francani V, Gattinoni P (2010) Depletion risk assessment of the Nossana Spring (Bergamo, Italy) based on stochastic modelling of the recharge. Hydrogeol Journ 18: 325-337.

Gattinoni P, Scesi L (2007) Roughness control on hydraulic conductivity in fractured rocks. Hydrogeology Journal 15: 201-211.

Gattinoni P, Scesi L (2009) Water Circulation in Rocks. Springer, ISBN: 978-90-481-2416-9, pp. 1-165.

Gattinoni P, Scesi L (2010) An empirical equation for tunnel inflow assessment: the application to a case history in sedimentary rock masses. Hydrogeology Journal DOI: 10.1007/s10040-010-0674-1.

Goodman RE, Moye DG, Van Schalkwyk A, Javandel I (1965) Ground 
water inflow during tunnel driving. Eng Geol 2: 39-56.

Gueguen Y, Dienes J (1989) Transport properties of rocks from statistics and percolations. J Int Assoc for Math Geology 21: 1-13.

Hantush MS (1966) Analysis of data from pumping tests in anisotropic aquifers. J Geophys Res 71(2):421-426

Harbaugh AW, Banta ER, Hill MC, McDonald MG (2000) MODFLOW-2000, the U.S. Geological Survey modular ground-water model-user guide to modularization concepts and the ground-water flow process. U.S. Geological Survey open-file report 00-92, 121 pp.

Kazemi H (1969) Pressure transient analysis of naturally fractured reservoirs with uniform fracture distribution. Soc Pet Eng J 9: 451462.

Kiraly L, Mathey B, Tripet JP (1971) Fissuration et orientation des cavités souterraines : règion de la Grotte de Milandre (Jura tabulaire) "Cracking and orientation of the subsurface hollows: Grotte de Milandre (French Jura) area". Bull Soc Neuchateloise Sc Nat 94: 99-114.

Kraemer SR, Haitjema HM (1989) Regional modelling of fractured rock aquifers. In Jousma $\mathrm{G}$ et al. (eds) "Groundwater Contamination: Use of Models in Decision-Making" Kluwer Academic Publishers, Dordrecht, pp. 467-476.

La Pointe PL, Wallmann PC, Follin S (1996) Continuum modelling of fractured rock masses: is it usefull?. In Barla G (ed) "Eurock 96", Balkema, Rotterdam, pp. 343-350.

La Vigna F, Hill MC, Rossetto R, Mazza R (2016) Parameterization, sensitivity analysis, and inversion: an investigation using groundwater modeling of the surface-mined Tivoli-Guidonia basin (Metropolitan City of Rome, Italy). Hydrogeol Journal 24(6): 1423-1441.

La Vigna F., Mazza R., Capelli G (2013) Detecting the flow relationships between deep and shallow aquifers in an exploited groundwater system, using long-term monitoring data and quantitative hydrogeology: the Acque Albule basin case (Rome, Italy). Hydrological Processes 27: 3159-3173.

Lee CH, Farmer I (1993) Fluid flow in discontinuous rocks. Chapman\&Hall, New York.

Liu J, Elsworth D, Brady BH, Muhlhaus HB (2000) Strain-dependent fluid flow defined through rock mass classification schemes. Rock Mech Rock Eng 33(2): 75-92.

Long JCS, Witherspoon PA (1985) The relationship of the degree of interconnection to permeability of fracture networks. J Geophys Res 90(B4): 3087-3098.

Louis C (1974) Introduction à l'hydraulique des roches. Bur Rech Geol Min 4/3: 283-356.

Lugeon M (1933) Barrage et Geology "Dams and geology". Dunod, Paris.

Maréchal JC, Dewandel B, Subrahmanyam K, Torri R (2008) Various Pumping Tests and Methods for Evaluation of Hydraulic Properties in Fractured Hard Rock Aquifers. Groundwater Dynamics in Hard Rock Aquifers, pp. 100-111 Springer.

Meyer T, Einstein HH (2002) Geologic stochastic modeling and connectivity assessment of fracture systems in the Boston Area. Rock Mech Rock Eng 35(1): 23-44.

Min KB, Jing L, Stephansson O (2004) Determining the equivalent permeability tensor for fractured rock masses using a stochastic REV approach: method and application to the field data from Sellafield, UK. Hydrogeology Journal 12(5): 497-510.

Molinero J, Samper J, Juanes R (2002) Numerical modelling of the transient hydrogeological response produced by tunnel construction in fractured bedrocks. Engineering Geology 64: 369-386.
Moutsopoulos KN, Konstantinidis AA, Meladiotis ID, Tzimopoulos CD, Aifantis EC (2001) Hydraulic and contaminant transport in multiple porosity media. Transport Porous Media 42: 265-292.

Neuman SP, Walter GR, Bentley HW, Ward JJ, Gonzalez DD (1984) Determination of Horizontal Aquifer Anisotropy with Three Wells. Ground Water 22(1): 66-72.

Pahl PJ (1981) Estimating the mean length of discontinuity trace. Int J Rock Mech Min Sci \& Geom Abstr 18: 221-228.

Papadopulos IS (1965) Nonsteady flow to a well in an infinite anisotropic aquifer. In Proceedings of Dubrovnik Symposium on the Hydrology of Fractured Rocks, International Association of Scientific Hydrology, Dubrovnik, Yugoslavia, pp 21-31.

Pappalardo G (2018) First results of infrared thermography applied to the evaluation of hydraulic conductivity in rock masses. Hydrogeol Journal 26: 417-428.

Raven KG, Gale JE (1976) Evaluation of structural and groundwater conditions in underground mines and excavations: subsurface containment of solid radioactive wastes. Geol Survey of Canada, Progress Report EMR/JSC-RW

Ren F, Ma G, Fan L, Wang Y, Zho H (2017) Equivalent discrete fracture networks for modelling fluid flow in highly fractured rock mass. Eng Geol 229: 21-30.

Robinson PC (1982) Connectivity of fracture system - A percolation theory approach. Theoretical Physics Division, AERE Arwell, DOE report n. DOE/RW/81.028.

Rong G, Peng J, Wang X, Liu G, Hou D (2013) Permeability tensor and representative elementary volume of fractured rock masses. Hydrogeol Journal 21: 1655-1671.

Rouleau A, Gale JE (1985) Statistical characterization of the fracture system in the Stripa Granite, Sweden. Int J Rock Mech Min Sci \& Geomech Abstr 22: 353-367.

Scanlon BR, Mace RE, Barret ME, Smith B (2003) Can we simulate regional groundwater flow in a karst system using equivalent porous media models? Case study, Barton Springs Edwards aquifer, USA. Journal of Hydrology 276:137-158.

Scesi L, Papini M, Gattinoni P, Longoni L (2015) Geologia Tecnica "Technical geology". Casa Editrice Ambrosiana, p. 496.

Shante VKS, Kirkpatrick S (1971) Introduction to percolation theory. Adv Phys 20: 325-357.

Snow DT (1969) Anisotropic permeability of fractured media. Water Resources Res 5 .

Snow DT (1970) The frequency and apertures of fractured rock. Int J Rock Mech Min Sci 7.

Tweed SO, Weaver TR, Cartwright I (2005) Distinguishing groundwater flow paths in different fractured-rock aquifers using groundwater chemistry: Dandenong Ranger, southeast Australia. Hydrogeology Journal 13: 771-786.

Vigna B (2001) Gli acquiferi carsici "The karsts aquifers". Quaderni didattici SSI 12: 3-48.

Yang T, Liu HY, Tang CA (2017) Scale effect in mascroscopic permeability of jointed rock mass using a coupled stress-damage-flow method. Eng Geol 228: 121-136.

Van Tonder G, Bardenhagen I, Riemann K, Van Bosch J, Dzanga P, $\mathrm{Xu} \mathrm{Y} \mathrm{(2002)} \mathrm{Manual} \mathrm{on} \mathrm{pumping} \mathrm{test} \mathrm{analysis} \mathrm{in} \mathrm{fractured} \mathrm{rock}$ aquifers. Institute for Groundwater Studies University of the Free State, Bloemfontein, WRC Report No III6/1/02. ISBN No 186845 $861 \mathrm{X}$. 